\title{
Audiodeskrypcja kluczem do świata kultury i sztuki dla osób z niepełnosprawnościq̨ wzroku
}

STRESZCZENIE: Przełom XX i XXI w. to okres wzrostu zainteresowania tematyką niepełnosprawności. Stopniowo zwiększa się liczba inicjatyw mających na celu integrację społeczną osób z niepełnosprawnością oraz poprawę warunków ich życia. Wciąż zbyt mało działań ukierunkowanych jest na umożliwienie im uczestnictwa w życiu kulturalnym. Problem ten dotyczy w szczególności osób z niepełnosprawnością sensoryczną. Niniejszy artykuł poświęcony będzie zasygnalizowaniu tej kwestii na przykładzie wybranej grupy - osób z niepełnosprawnością wzrokową. W pierwszej kolejności zostaną omówione ograniczenia w sferze percepcji i komunikacji wynikające z uszkodzenia narządu wzroku. Pozwoli to wskazać dziedziny twórczości artystycznej oraz te aspekty dzieła sztuki, które pozostają niedostępne dla osób niewidzących. W dalszej części artykułu zostanie przedstawiona technika audiodeskrypcji, dzięki której kultura i sztuka stają się dostępna dla osób z niepełnosprawnością wzroku.

SŁOWA KLUCzowE: audiodeskrypcja, dostęp do kultury i sztuki, osoby z niepełnosprawnością wzroku.

* Uczestniczka studiów doktoranckich z zakresu bibliologii prowadzonych na Wydziale Nauk Historycznych Uniwersytetu Mikołaja Kopernika w Toruniu. 


\section{Wprowadzenie}

T

emat niepełnosprawności przez wiele lat osadzony był poza centrum zainteresowania społeczeństwa. Jeszcze do niedawna osoby z różnego rodzaju dysfunkcjami znajdowały się na marginesie życia publicznego. Do wzrostu zainteresowania Polaków tą tematyką w dużym stopniu przyczyniły się inicjatywy na rzecz poprawy sytuacji osób z niepełnosprawnością podejmowane na całym świecie. Okresem przełomowym pod tym względem były lata 80. XX w. Światowy Rok Osób Niepełnosprawnych (1981) oraz Dekada Osób Niepełnosprawnych (1982-1993) - obydwa ustanowione przez Organizację Narodów Zjednoczonych - skutecznie zwróciły uwagę świata na to zagadnienie ${ }^{1}$. W Polsce tematyka ta na dobre zagościła w piśmiennictwie i w mediach po przełomie ustrojowym, do którego doszło w 1989 r.

Zwrócenie się społeczeństwa ku problemom osób z niepełnosprawnością zaowocowało stopniowym poszerzaniem się wachlarza oferowanych im udogodnień: od regulacji prawnych, przez podejmowanie inicjatyw zmierzających ku integracji społecznej, po przystosowywanie obiektów użytku publicznego do ich potrzeb. Nadal jednak wiele pozostaje do zrobienia. W powszechnej świadomości wciąż pokutuje stereotypowe wyobrażenie osoby niepełnosprawnej jako przykutej do wózka inwalidzkiego, a więc niepełnosprawnej fizycznie. Za „przystosowany” do jej potrzeb uważa się zatem obiekt mający udogodnienia architektoniczne, choć to dopiero pierwszy krok na drodze do wszechstronnego przystosowania. Wiedza na temat potrzeb osób z innego rodzaju niepełnosprawnościami - intelektualną czy sensoryczną - wciąż jest niewystarczająca. Liczba przygotowanych z myślą o nich udogodnień w ostatnim czasie powoli wzrasta - niesłyszący mogą już korzystać z usług tłumacza języka migowego w urzędach, osobom niewidzącym przysługują dofinansowania m.in. na zakup komputerów wyposażonych w programy udźwiękawiające ${ }^{2}$. Tego rodzaju formy wsparcia podnoszą jakość życia

1 Działalność ONZ [online] [dostęp 31 maja 2016]. Dostępny w World Wide Web: http://www.unic.un.org.pl/niepelnosprawnosc/dzialalnosc.php?druk=1.

2 Zob. Ustawa z dnia 19 sierpnia 2011 r. o języku migowym i innych środkach komunikowania się, Dz.U. 2011, nr 209, poz. 1243, art. 11, pkt 1-3; Program „Aktywny Samorząd” 
osób z niepełnosprawnością, gwarantując im pomoc w czynnościach życia codziennego. Potrzeby kulturalne jednak pozostają zwykle na drugim planie. Przyczyn takiego stanu rzeczy można upatrywać w wielu czynnikach: w trudnej sytuacji finansowej osób z niepełnosprawnością, w braku dostosowania obiektów kulturalnych do ich potrzeb, w traktowaniu osób z niepełnosprawnościami w kategoriach „inności” i nieprzyzwyczajeniu społeczeństwa do ich obecności w życiu publicznym. Największą barierą w dostępie osób z niepełnosprawnością do kultury i sztuki jest jednak, sygnalizowany już wcześniej, brak wiedzy na temat specyfiki poszczególnych rodzajów dysfunkcji i wynikających z nich ograniczeń. Konsekwencją tego jest nieumiejętność organizowania wydarzeń o charakterze kulturalnym i prezentowania dzieł sztuki w taki sposób, aby były one dostępne dla osób z niepełnosprawnością, w tym dla ludzi z uszkodzonym wzrokiem.

\section{Niepetnosprawność wzroku - definicja i typologia}

Termin niepełnosprawność jest niezwykle pojemny, ponieważ odnosi się do różnego rodzaju ograniczeń i dysfunkcji ludzkiego organizmu. Pojęcie niepełnosprawności leży w kręgu zainteresowania wielu dziedzin nauki, m.in. medycyny, psychologii, pedagogiki czy prawa. Z tego powodu ustalenie jego jednoznacznej, uniwersalnej definicji jest niemożliwe. Dla celów niniejszego artykułu istotne jest określenie znaczenia terminów niepełnosprawność i niepełnosprawność wzrokowa oraz umiejscowienie drugiego z nich wśród rodzajów uszkodzeń. Obie kwestie sprecyzowane są w Konwencji ONZ o prawach osób niepełnosprawnych ${ }^{3}$. Definicja zawarta w artykule 1. Konwencji brzmi następująco:

[online] [dostęp 31 marca 2016]. Dostępny w World Wide Web: http://www.pfron.org. $\mathrm{pl} / \mathrm{pl} /$ programy-i-zadania-pfr/aktywny-samorzad/1644,Pilotazowy-program-Aktywnysamorzad.html.

${ }^{3}$ Jest to jeden z wielu dokumentów regulujących sytuację prawną osób z niepełnosprawnościami obowiązujący w polskim prawodawstwie. Wśród innych ważnych aktów wymienić można m.in. Uchwałę Sejmu Rzeczypospolitej Polskiej z dnia 1 sierpnia 1997 r. - Karta Praw Osób Niepełnosprawnych, M. P. 1997, nr 50, poz. 475; Ustawę o rehabilitacji zawodowej i społecznej oraz zatrudnianiu osób niepełnosprawnych, Dz.U. 1997, nr 123, poz. 776. 
Do osób niepełnosprawnych zalicza się te osoby, które mają długotrwale naruszoną sprawność fizyczną, umysłową, intelektualną lub w zakresie zmysłów, co może, w oddziaływaniu z różnymi barierami, utrudniać im pełny i skuteczny udział w życiu społecznym na zasadzie równości z innymi osobami ${ }^{4}$.

Typologia uszkodzeń zawarta w definicji uwzględnia niepełnosprawność fizyczną, psychiczną i umysłową oraz związaną ze zmysłami (niepełnosprawność sensoryczna). W literaturze przedmiotu często przytaczany jest również podział niepełnosprawności na trzy rodzaje: fizyczną, psychiczną i sensoryczną. Każdy z nich, na skutek barier występujących w otoczeniu, może powodować określone konsekwencje dla funkcjonowania osoby z niepełnosprawnością. Szczególnie zagrożoną sferą jest życie społeczne.

Niepełnosprawność wzroku wynika z uszkodzenia narządów zmysłów i zaliczana jest do niepełnosprawności sensorycznych (do tej grupy uszkodzeń należy również niepełnosprawność słuchowa oraz wzrokowo-słuchowa, czyli tzw. niepełnosprawność sprzężona) ${ }^{6}$. Osoby z niepełnosprawnością wzroku to grupa niejednorodna. W zależności od przyczyny występowania uszkodzeń oraz od stopnia ich rozległości osoby z dysfunkcjami wzroku dzieli się na dwie zasadnicze grupy: niewidzących i niedowidzących (słabowidzących). W grupie osób niewidzących znajdują się zarówno ludzie niewidomi, jak też ociemniali. Pierwsze pojęcie dotyczy osób ze ślepotą wrodzoną lub nabytą przed 4-5 rokiem życia (osoby te nie pamiętają okresu sprzed utraty wzroku). Osoby ociemniałe to te, które straciły wzrok (stopniowo lub w wyniku nagłego zdarzenia) po 4-5 roku życia, a więc pamiętają bodźce wzrokowe w tym większym

${ }^{4}$ Konwencja o prawach osób niepetnosprawnych, Dz.U. 2012, poz. 1169, art. 1. Konwencja została sporządzona w Nowym Jorku dn. 13 grudnia 2006 r., była ratyfikowana przez Polskę dn. 6 września 2012 r.

${ }^{5}$ W. Dykcik, Wprowadzenie w przedmiot pedagogiki specjalnej jako nauki, [w:] Pedagogika specjalna, pod red. W. Dykcika, Poznań 2002, s. 15.

${ }^{6}$ M. Czerwińska, Osoby z niepełnosprawnością wzroku, [w:] H. Ochonczenko, M. Czerwińska, M. Garbat, Osoby z niepełnosprawnościq w szkole wyższej. Wybrane zagadnienia, Zielona Góra 2011, s. 11. Por. M. Fedorowicz, Człowiek niepełnosprawny w bibliotece publicznej, Toruń 2010, s. 16-17. 
stopniu, im później nastąpiła utrata wzroku. Do drugiej grupy należą osoby niedowidzące w różnym stopniu?.

Inna, powszechnie znana klasyfikacja zakłada podział osób z niepełnosprawnością wzroku na pięć grup:

1. osoby o $V=0,00$, ze ślepotą medyczną (czarną, rzeczywistą) osoby bez poczucia światła;

2. osoby o $\mathrm{V}=0,02$, z poczuciem światła - mogące policzyć palce z odległości ok. 1 metra;

3. osoby o $\mathrm{V}=0,02$ do 0,05 , osoby $\mathrm{w}$ wysokim stopniu niedowidzące/szczątkowo widzące/osoby z resztkami widzenia/osoby dotknięte ślepotą społeczną (praktyczną) - mogą policzyć palce z odległości ok. 3 metrów;

4. osoby z V=0,05-0,1, niedowidzące (słabowidzące) - nawet z zastosowaniem przyrządów optycznych nie są w stanie czytać zwykłego druku;

5. osoby z V=0,1-0,3 - mogą czytać zwykły druk przy użyciu przyrządów optycznych, ale nie mogą wykorzystywać wzroku do czytania ani do pracy ${ }^{8}$.

Podstawą podziału jest w tym przypadku ostrość widzenia (V), a zatem stosunek pomiędzy odległością, z jakiej widziany jest dany obiekt, a tą, z której powinien być on widziany przy prawidłowo funkcjonującym narządzie wzroku'.

Ważnym kryterium podziału osób z uszkodzonym wzrokiem jest również pole widzenia (C). Pojęciem tym określa się zakres widzenia obwodowego mierzony w stopniach kątowych. Prawidłowa wartość pola widzenia dla jednego oka w pionie wynosi ok. $120^{\circ}$, a w poziomie ok. $150^{\circ}$ (przy prawidłowym widzeniu obuocznym wartość ta wynosi ok. $\left.200^{\circ}\right)^{10}$. Zaburzenia w obrębie pola widzenia mogą polegać na ubytku koncentrycznym, połowicznym lub wysepkowym. Osoby z koncentrycznym zaburzeniem pola widzenia dzieli się na następujące grupy:

1. osoby z niewielkim zaburzeniem - średnica pola widzenia nieprzekraczająca $120^{\circ}$,

\footnotetext{
7 M. Czerwińska, dz. cyt., s. 12.

8 Tamże, s. 13.

9 Tamże.

10 Tamże, s. 14.
} 
2. osoby z umiarkowanym zaburzeniem - średnica pola nieprzekraczająca $60^{\circ}$,

3. osoby z zaburzeniem znacznym - średnica pola widzenia nieprzekraczająca $20^{\circ}$,

4. osoby z zaburzeniem głębokim - średnica pola widzenia wynosząca mniej niż $5^{\circ}$ (tak znaczny ubytek w zakresie pola widzenia nazywany jest widzeniem lunetowym) ${ }^{11}$.

Inne zaburzenia wzroku wyodrębnia się w odniesieniu do procesu widzenia. Proces ten uzależniony jest od prawidłowego funkcjonowania narządu wzroku. Narząd wzroku człowieka składa się z gałek ocznych, mięśni umożliwiających ich ruch oraz nerwów wzrokowych, które łączą gałki oczne z komórkami nerwowymi w ośrodku wzrokowym (płat potyliczny kory mózgowej). Zakończenia nerwów wzrokowych umieszczone są w siatkówce (dno oka), gdzie tworzą receptory wzrokowe (czopki i pręciki), a więc komórki światłoczułe, które reagują na bodźce wzrokowe $^{12}$. Proces widzenia zachodzi w aspekcie fizjologicznym i psychologicznym. W obrębie pierwszego z nich wyróżnia się czynności motoryczne, optyczne oraz wzrokowe. Czynności motoryczne uzależnione są od zjawiska konwergencji - możliwości kierowania gałek ocznych na postrzegany obiekt oraz zdolności śledzenia obiektu będącego w ruchu. Podstawą czynności optycznych jest refrakcja - prawidłowe załamywanie się wiązki impulsu światła na powierzchni przeziernych elementów oka: rogówki, soczewki i ciałka szklistego, a następnie kierowanie impulsu na plamkę żółtą siatkówki. Czynności wzrokowe zachodzą na dnie oka (w siatkówce). Ich zadanie polega na reagowaniu na bodźce świetlne (reakcja zachodzi w obrębie receptorów wzrokowych) i przekazywaniu powstających w ten sposób pobudzeń do ośrodka widzenia w korze mózgowej ${ }^{13}$.

Na podstawie procesu widzenia wyróżnia się następujące czynności narządu wzroku:

- $\quad$ widzenie centralne (widzenie plamką żółtą) - zapewnia możliwość czytania, postrzegania obiektów o małych rozmiarach, postrzeganie detali. Widzenie centralne mierzone jest na podstawie kryterium ostrości wzroku (zdolności rozróżnienia dwóch punk-

\footnotetext{
11 Tamże.

12 Tamże, s. 12.

13 Tamże.
} 
tów znajdujących się w maksymalnym przybliżeniu względem siebie). Osoba, której wzrok funkcjonuje w sposób prawidłowy, z odległości $25 \mathrm{~cm}$ jest w stanie dostrzec dwa punkty oddalone od siebie o $0,07 \mathrm{~mm}$.

- widzenie obwodowe (widzenie komunikacyjne, widzenie całą siatkówką) - umożliwia percepcję obiektów o dużych rozmiarach, percepcję obiektów będących w ruchu oraz orientację w przestrzeni. Widzenie obwodowe mierzone jest zakresem pola widzenia.

- widzenie stereoskopowe (widzenie obuoczne) - zapewnia możliwość postrzegania trójwymiarowego, percepcję perspektywy, głębi i horyzontu.

- widzenie barwne - umożliwia percepcję barw.

- widzenie nocne - umożliwia percepcję w warunkach niewystarczającego oświetlenia ${ }^{14}$.

U osób z niepełnosprawnością wzroku wymienione czynności mogą przebiegać w sposób nieprawidłowy, a stopnień zaburzenia procesu widzenia uzależniony jest od charakteru i rozmiaru występujących dysfunkcji.

Etiologia uszkodzeń narządu wzroku jest zróżnicowana. Wśród przyczyn determinujących ich występowanie wyróżnia dwie ogólne grupy czynników: wewnętrzne (wrodzone, genetyczne, chorobowe) oraz zewnętrzne (uszkodzenia mechaniczne, urazy) ${ }^{15}$.

\section{Niepetnosprawność wzroku a dostęp do kultury i sztuki}

Fakt, iż bodźce wzrokowe dostarczają człowiekowi 80-90\% informacji o otaczającym świecie, nie pozostawia wątpliwości co do tego, że wzrok jest najważniejszym dla człowieka zmysłem ${ }^{16}$. Niepełnosprawność narządu wzroku niesie za sobą określone konsekwencje dla każdego aspektu

14 Tamże, s. 12-13.

15 Tamże, s. 15. Szerzej nt. etiologii uszkodzeń narządu wzroku zob. J. Kirenko, P. Gindrich, Odkrywanie niepetnosprawności wzrokowej w nauczaniu włączającym, Lublin 2007, s. 69-72.

${ }^{16}$ M. Czerwińska, dz. cyt., s. 16. 
życia człowieka. Brak zmysłu wzroku lub znaczne jego uszkodzenie, szczególnie występujące od wczesnych lat dzieciństwa, w przypadku niepodejmowania działań rehabilitacyjnych może powodować liczne zaburzenia w rozwoju człowieka. Są to m.in. nieprawidłowości w rozwoju sfery motorycznej, percepcji i komunikacji ${ }^{17}$. Trudności, jakie może napotykać osoba niewidząca, występują równocześnie we wszystkich wskazanych obszarach. W zależności od rodzaju uszkodzenia mogą one przeważać w jednym z nich. Brak lub ograniczenie percepcji wzrokowej kompensowane jest poprzez wykorzystywanie pozostałych zmysłów. Mechanizm ten nazywany jest kompensacją poznawczą (kognitywną), a w odniesieniu do zmysłów - kompensacją sensoryczną ${ }^{18}$.Zdolność kompensacji wyjaśnić można w odniesieniu do dynamicznych układów strukturalnych, które tworzą się na poziomie pierwszego i drugiego układu sygnałowego. Wykształcenie się umiejętności z obszaru pierwszego układu sygnałowego (odbieranie podstawowych bodźców ze środowiska zewnętrznego) warunkuje możliwość kształtowania się umiejętności w obrębie drugiego układu sygnałowego (czytanie, pisanie, zdolność komunikowania się, możliwość wykonywania czynności samoobsługowych) ${ }^{19}$. Zmysłem odgrywającym najistotniejszą rolę w procesie kompensacji jest zmysł dotyku. Umożliwia on określenie takich cech percypowanego przedmiotu, jak: kształt, twardość, opór czy ciężar. Dotyk może mieć charakter syntetyczny (bierny) lub analityczny (czynny). Wykorzystując dotyk syntetyczny, osoba pozbawiona zmysłu wzroku może wytworzyć w wyobraźni schematy przedmiotów. Dotyk czynny daje natomiast możliwość poznania detali ich budowy. Zmysł dotyku funkcjonuje w połączeniu z układem mięśniowo-ruchowym oraz ze zmysłem słuchu i powonienia. Dotykowe poznanie rzeczywistości ma dwie odmiany. Pierwszą jest poznanie ogólne, które pozwala zbudować wyobrażenie na temat najbardziej charakterystycznych cech przedmiotu. Z kolei poznanie formy polega na zbadaniu szczegółów budowy percypowanego obiektu. Ogólne schematy dotykowe

${ }^{17}$ Konsekwencje uszkodzenia narządu wzroku szerzej omawia m.in. M. Czerwińska w przywoływanej już publikacji Osoby z niepełnosprawnościq wzrok... Por. też M. Zaorska, Głuchoniewidomi w Polsce. Specjalna pomoc, edukacja i rehabilitacja, Olsztyn 2002, s. 52-53.

${ }^{18}$ Z. Sękowska, Pedagogika specjalna. Zarys, Warszawa 1985, s. 70-72. Por. M. Czerwińska, dz. cyt., s. 17.

19 Z. Sękowska, dz. cyt., s. 70-72. Por. M. Zaorska, dz. cyt., s. 55. 
tworzą się u osób niewidzących około 10-11 roku życia i są mniej trwałe niż formy ${ }^{20}$. Warto zauważyć, że oprócz dłoni wykorzystywane są również inne części ciała, np. stopy, język, wargi. Bodźce z otoczenia odbierane są także dzięki zmysłom słuchu, węchu i smaku, a komunikacja realizowana jest poprzez mowę werbalną ${ }^{21}$. Mechanizm kompensacji, choć stanowi niezwykle wartościową alternatywę dla wrażeń wzrokowych, nie może ich zastąpić w stu procentach.

\section{Oddziaływanie sztuki na odbiorce}

Aby ustalić, które ze wskazanych obszarów funkcjonowania człowieka są najistotniejsze w kontekście uczestnictwa w wydarzeniach kulturalnych oraz w odbiorze sztuki, należy zastanowić się nad tym, w jaki sposób sztuka oddziałuje na odbiorcę. Kwestię tę wyjaśnia Umberto Eco:

Ogólnie ujmując, w pojęciu „dzieło sztuki” zawarte są implicite dwa aspekty: 1) autor tworzy rzecz skończoną i określoną, według jakiegoś precyzyjnego zamysłu, nastawiając się na odbiór, który będzie reinterpretacją owej rzeczy zgodnie z tym, co autor zamierzał i chciał; 2) jednak owa rzecz zostaje odbierana przez wielu odbiorów, z których każdy wnosi do aktu odbioru własne cechy psychologiczne i fizjologiczne, swoje ukształtowanie środowiskowe i kulturowe, tę charakterystykę wrażliwości, jaką narzucają bezpośrednie okoliczności i sytuacja historyczna; a zatem każdy odbiór - niezależnie od uczciwego i bezwarunkowego wysiłku, aby dochować dziełu wierności - jest nieuchronnie osobisty i oddaje dzieło $\mathrm{w}$ jednym z jego możliwych aspektów ${ }^{22}$.

Dzieło sztuki jest więc komunikatem, za pośrednictwem którego autor ( $\mathrm{w}$ tym wypadku nadawca komunikatu) porozumiewa się z odbiorcą. Ten z kolei postrzega dzieło przez pryzmat własnych umiejętności i do-

20 Z. Sękowska, dz. cyt., s. 70-72. Por. M. Czerwińska, dz. cyt., s. 17-18.

21 Z. Sękowska, dz. cyt., s. 61-66. Por. np. M. Fedorowicz, Specjalne materiały czytelnicze dla osób niepełnosprawnych, Toruń 2002, s. 15-16.

${ }^{22}$ U. Eco, Sztuka, przeł. P. Salwa, M. Salwa, Kraków 2008, s. 167-168. 
świadczeń, interpretuje je we właściwy dla siebie, indywidualny sposób. Jest oczywiste, że charakter dzieła wpływa na sposób jego odbioru. Inaczej percypowany jest utwór narracyjny, a inaczej wizualny czy audiowizualny. Różnica pomiędzy interpretacją sztuki „wykorzystującej słowa-pojęcia a sztuką wykorzystującą obrazy" przedstawia się następująco:

Trzeba zauważyć, że w tym pierwszym przypadku (literatura) odbiorca reaguje na znak językowy, który wprawdzie odbiera się w postaci zmysłowej, ale który można wykorzystać jedynie na drodze dość skomplikowanej, chociaż spontanicznej operacji, polegającej na eksploracji „pola semantycznego" związanego z tym znakiem, aż do momentu, w którym, w powiązaniu z informacjami płynącymi z kontekstu, odpowiednio zrozumiany znak wywoła również pewną liczbę obrazów zdolnych do emocjonalnego pobudzenia odbiorcy. $\mathrm{W}$ przeciwieństwie do tego, w przypadku pobudzania za pomocą obrazu [...] przebieg jest dokładnie odwrotny: pierwszym bodźcem jest wrażenie zmysłowe, jeszcze niezracjonalizowane i konceptualnie nieuformowane, odbierane wraz z całym ładunkiem emocjonalnym, jaki obraz za sobą niesie ${ }^{23}$.

Zarówno dzieło sztuki operujące słowem, jak też utwór o charakterze pozajęzykowym percypowane są za pomocą zmysłów. Utwór językowy może być odbierany poprzez zmysł wzroku lub słuchu. Z kolei dzieło wizualne dostępne jest wyłącznie dzięki pierwszemu z nich. Odnosząc się do wzrokowego postrzegania dzieła sztuki (językowego i pozajęzykowego), należy podkreślić, iż wzrok odgrywa rolę „pośrednika”, którego zadaniem jest przekazanie bodźca do sfery intelektualnej w celu jego dalszego „przetworzenia”. Obraz pobudza wyobraźnię odbiorcy i powoduje, że postrzeżony obiekt zostaje poddany interpretacji. Postrzeżenie i interpretacja są zatem czynnikami, które wspólnie warunkują odbiór dzieła sztuki:

Analiza przeżyć estetycznych [...] jest dosyć skomplikowana. Musimy w nich wyróżnić co najmniej dwa procesy współczesne: postrzeganie

23 Tamże, s. 205-206. 
przedmiotu i semantyczną interpretację; np. czytam i rozumiem, patrzę na akwarelę i wyobrażam sobie rzeczywistość uchwyconą przez malarza. Przedmiot wyobrażony nie wypiera z naszej świadomości całkowicie przedmiotu postrzeganego, lecz się z nim jakoś łączy w jednym przeżyciu. Możemy również przenosić uwagę z przedmiotu postrzeganego na wyobrażony i odwrotnie; możemy je ze sobą porównywać. Ta gra dwóch rzeczywistości nadaje specjalny charakter przeżyciom estetycznym, doznawanym wobec pewnych dzieł ludzkich ${ }^{24}$.

Percepcja dzieła i jego interpretacja to procesy, które zachodzą równocześnie, umożliwiając odbiorcy przeżycie estetyczne. W przeżyciu tym obecne są dwie rzeczywistości. Jedną z nich jest wyobrażenie powstające pod wpływem kontaktu z dziełem sztuki. Wyobrażenie to stanowi interpretację dzieła-komunikatu nadanego przez autora-twórcę. Drugą rzeczywistością jest postrzeganie realnego obiektu, w odniesieniu do którego powstaje wyobrażenie. Procesy intelektualne, za pomocą których odbiorca percypuje dzieło, zapewniają mu możliwość przechodzenia pomiędzy wymiarem realnym i wyobrażeniowym. Oba te wymiary budują przestrzeń, w której zachodzi przeżycie estetyczne.

Proces interpretacji dzieła sztuki uzależniony jest od trzech czynników:

Stosunku wyobrażania nie wyznaczają nam żadne obiektywne cechy obrazu i przedmiotu wyobrażonego, aczkolwiek mogą być niezbędnymi warunkami zachodzenia tego stosunku. Wynika to stąd, że obraz jest przedmiotem reprezentatywnym; pełni pewną funkcję semantyczną. Wiemy, że wszelka funkcja semantyczna zależna jest od postawy obserwatora: przedmiot pełni swą funkcję semantyczną tylko dla kogoś, kto go w odpowiedni sposób interpretuje. Pojęcie wyobrażania i pojęcie obrazu musimy tedy zrelatywizować ze względu na interpretację obserwatorów. Oczywiście takim obserwatorem jest przede wszystkim sam twórca. Przedmiot jest obrazem, jeżeli ktoś zajmuje względem niego postawę semantyczną, przy czym ów inny

${ }^{24}$ S. Ossowski, U podstaw estetyki, Warszawa 1958, s. 79. 
przedmiot, na który przenosi się myśl obserwatora, jest zdeterminowany przez podobieństwo wyglądów ${ }^{25}$.

Pierwszym czynnikiem warunkującym przeżycie estetyczne jest postawa odbiorcy, który obserwując obiekt, podejmuje próbę jego zinterpretowania, a więc odniesienia go do zasobu własnych możliwości intelektualnych oraz do własnej wrażliwości emocjonalnej. Drugim czynnikiem jest obiekt będący dziełem sztuki. Jego indywidualne cechy nie podlegają ocenie pod względem wartości estetycznej, gdyż obiekt, w ujęciu całościowym, stanowi reprezentację zamysłu twórcy. Jako element rzeczywistości realnej dzieło jest tylko obiektem. Dopiero po odniesieniu tego obiektu do rzeczywistości wyobrażeniowej staje się on dziełem-obrazem. Trzecim elementem przeżycia estetycznego jest autor. Wobec swego dzieła przyjmuje on zarówno postawę nadawcy, jak też pozycję obserwatora. Autor, tworząc dzieło sztuki, musi zachować relację zgodności pomiędzy rzeczywistością realną i wyobrażeniową. Innymi słowy, dzieło jako obiekt musi stanowić odwzorowanie zamysłu twórczego, który klaruje się w wyobraźni autora i ma zostać przekazany odbiorcy. Warto zauważyć, że aby interpretacja dzieła dokonywana przez odbiorcę była zbieżna z zamysłem autora, musieliby oni dysponować tym samym zasobem doświadczeń i posiadać podobną (lub wręcz taką samą) wrażliwość estetyczną.

Wpływ osoby odbiorcy na interpretację dzieła sztuki przedstawia się następująco:

Uwarunkowanie odbioru dzieł sztuki przez wrażliwość estetyczną, indywidualną i zmienną, sprawia, że dzieło sztuki jawi się odmiennie zależnie od tego, jaki jest odbiorca. Odbiorca dokonuje samorzutnie selekcji właściwości dzieł sztuki, a te właśnie cechy wyselekcjonowane ulegają rozmaitym transformacjom w zależności od indywidualnych właściwości odbiorcy, od tego, jak jest ukształtowana jego świadomość, jaką specyficzną odmianę stanowi jego wrażliwość estetyczna, jego wyobraźnia, kultura osobista, słowem: zależnie od tego, jakie jest

25 Tamże, s. 81. 
a priori estetyczne odbiorcy i jaką postawę zajmuje on wobec sztuki i świata ${ }^{26}$.

Biorąc pod uwagę wielość czynników, które kreują osobowość odbiorcy, trudno oczekiwać, aby dokonana przez niego indywidualna interpretacja dzieła stanowiła wierne odwzorowanie zamysłu autora. Autor - również indywiduum - tworzy dzieło będące wyrazem jego własnych przekonań i emocji. Poza tym, przyjmując, że założeniem autora jest zaprezentowanie dzieła szerokiemu gronu adresatów, trzeba zakładać, iż różnorodność przeżyć estetycznych nim powodowanych będzie tak bogata, jak szerokie będzie grono odbiorców.

W podsumowaniu rozważań na temat warunków kształtowania się przeżycia estetycznego warto przyjrzeć się pojęciu piękna:

[...] piękno (resp. wartość estetyczna) jest własnością nie tylko dzieł sztuki, lecz także natury, myśli ludzkiej, ludzkich czynów oraz wytworów nie będących dziełami sztuki, z drugiej strony na przeświadczeniu, że wytwory artystycznej aktywności człowieka nie wyczerpują swej roli w dostarczaniu przeżyć estetycznych powiązanych z pięknem, ale że nadto mogą być obdarzone intencjami całkowicie pozaestetycznymi. Więcej, że te intencje pozaestetyczne, jak na przykład poznawcze, pragmatyczne czy ideologiczne, mogą faktycznie determinować i współkonstytuować funkcje dzieła sztuki i to nie tylko w wymiarze indywidualnym, ale i dziejowym, wyznaczając w procesie rozwojowym sztuki różne normatywne systemy oczekiwań co do roli, jaką pełnić powinno dzieło sztuki ${ }^{27}$.

Piękno jest wartością estetyczną. Cechą „bycia pięknym” odznacza się nie tylko dzieło sztuki, ale również natura ludzka. Teza ta potwierdza, jak duże znaczenie dla interpretacji dzieła ma osoba odbiorcy. Konfrontacja jego estetycznej (pięknej) natury z estetyczną (piękną) wartością dzieła daje wypadkową, którą jest przeżycie estetyczne - inne dla każdego od-

${ }^{26}$ M. Gołaszewska, Zarys estetyki. Problematyka, metody, teorie, Warszawa 1984, s. 287-288.

27 R. Ingarden, Sztuka i estetyka, [w:] R. Ingarden, Wybór pism estetycznych, oprac. A. Tyszczyk, Kraków 2005, s. XX. 
biorcy, oryginalne i niepowtarzalne. Roman Ingarden zauważa, że dzieło sztuki nie musi odznaczać się wartością estetyczną rozumianą jako „bycie pięknym". O wartości dzieła decyduje jego funkcja. Jeśli zatem zamiarem twórcy jest przekazanie np. treści ideologicznej, to estetyczna wartość utworu traci znacznie na rzecz wartości ideologicznej. Estetyczna lub pozaestetyczna wartość dzieła sztuki nie jest jedynie kwestią dobrowolnego wyboru twórcy. Zmienia się ona na przestrzeni dziejów wraz z rozwojem myśli ludzkiej i przekształceniami, jakie dokonują się w wymiarze oczekiwań wobec funkcji sztuki.

Nawiązując ponownie do zadania sztuki, którym jest komunikacja na linii autor - odbiorca, należy przyjąć, że do percepcji dzieła konieczna jest zdolność komunikowania się. Obszary te okazują się zatem równoważne, a zdolności z ich zakresów wzajemnie się uzupełniają ${ }^{28}$. Wniosek ten nasuwa pytanie o to, jakie elementy dzieła sztuki muszą być percypowane, aby „dialog” pomiędzy autorem i odbiorcą mógł przebiegać płynnie. I drugie, najważniejsze pytanie: które elementy dzieła mogą być odczytane przez osobę z niepełnosprawnością wzroku?

W celu udzielenia odpowiedzi na te pytania należy ustalić, jakie formy komunikacji są dostępne dla osób niewidzących i niedowidzących. Podstawowe sposoby porozumiewania się to komunikacja werbalna i niewerbalna. Do pierwszej z nich należy mowa ustna i pisemna. Obie realizowane są za pomocą języka. Mowa ustna na ogół odbywa się w sytuacji kontaktu nadawcy z odbiorcą, dlatego zapewnia możliwość sprzężenia zwrotnego - natychmiastowej reakcji na komunikat. Dodatkowo wzbogacona jest o informacje niewerbalne. Forma pisemna nie wymaga kontaktu pomiędzy uczestnikami aktu komunikacji, częściej ma charakter oficjalny ${ }^{29}$. Osoby z niepełnosprawnością wzroku, o ile nie występują u nich inne uszkodzenia sensoryczne, mogą swobodnie korzystać z formy ustnej. Komunikując się w formie pisemnej, osoby niewidzące wykorzystują systemy, w których nie używa się znaków zwykłego pisma, tzw. pisma czarnodrukowego, np. system Braille'a czy pismo Moona ${ }^{30}$. W celu nadania

${ }^{28}$ Chociaż rozwój zdolności motorycznych jest bardzo ważny (rzutuje na prawidłowe funkcjonowanie organizmu człowieka), to w kontekście poruszanej problematyki nie jest on istotny i nie będzie tu rozpatrywany.

${ }^{29}$ A. Benedikt, Mowa ciała, Wrocław 2002, s. 11-14.

${ }^{30}$ Zob. np. M. Mellor, Louis Braille, dotyk geniuszu, przeł. E. Zieliński, M. Kalbarczyk, Warszawa 2009, s. 59-67, 110. 
komunikatu o trwałym charakterze osoby niewidzące mogą korzystać z klasycznych urządzeń nagrywających dźwięk (dyktafony, magnetofony) oraz z urządzeń nowszej generacji (dyktafon cyfrowy ${ }^{31}$; odtwarzacz cyfrowy MILESTONE, posiadający funkcje nagrywania dźwięku, wyposażony w odtwarzacz plików dźwiękowych oraz książek audio w formacie DAISY32; nowoczesny magnetofon wielofunkcyjny Plex Talk PTR2, za pomocą którego możliwe jest nagrywanie i odczytywanie plików w formatach DAISY, audio, mp3 i CD ${ }^{33}$ ). Odczytanie tego typu komunikatów polega na ich odsłuchaniu (przy użyciu odtwarzacza, komputera). Wielość dostępnych form komunikowania się werbalnego sprawia, że osoby z niepełnosprawnością wzroku mają możliwość dostępu do sztuki operującej znakami językowymi (literatura).

Drugą formą jest komunikacja niewerbalna. W jej obrębie wyróżnia się trzy sposoby przekazywania informacji: struktura otoczenia oraz warunki, w jakich przebiega akt komunikacji, wygląd zewnętrzny uczestników komunikacji, zachowania eksponujące prezentowane przez uczestników sytuacji komunikacyjnej ${ }^{34}$. Przekaz komunikatów niewerbalnych odbywa się bez użycia znaków językowych. Środki stosowane w tym typie porozumiewania się to: pozaliterackie dzieła sztuki, wystrój pomieszczeń, plany sytuacyjne, przedmioty, którymi posługują się ludzie (w określonym kręgu zawodowym lub w danej sytuacji społeczno-demograficznej), statyczne i dynamiczne właściwości ciała ${ }^{35}$. Informacje te przekazywane są drogą wzrokową, leżą zatem poza granicami percepcji członków omawianej grupy.

Sztuka, w której wykorzystywane są znaki systemów pozajęzykowych, może być zupełnie niedostępna dla osób niewidzących lub dostępna w pewnym tylko stopniu. Osoby te nie mają możliwości bezpośredniego odbioru dzieł z zakresu sztuki wizualnej (np. malarstwo, fotografia). Istnieje jednak szereg dyscyplin, w obrębie których tworzy się dzieła poznawalne za pomocą kilku zmysłów równocześnie: rzeźba, film (można do nich też zaliczyć wydarzenia kulturalne o charakterze widowisko-

\footnotetext{
31 M. Kalbarczyk, Obok jest osoba niewidoma, Warszawa 2014, s. 31.

32 Tamże, s. 43-44.

33 Tamże, s. 44.

${ }^{34}$ A. Benedikt, dz. cyt., s. 15.

35 Tamże. Por. też Mosty zamiast murów. Podręcznik komunikacji interpersonalnej, pod red. J. Stewarta, Warszawa 2000, s. 76-105, 121-133.
} 
wym). Ich percepcja jest możliwa dzięki wykorzystaniu mechanizmu kompensacji opartego na całym zasobie percepcji (pozawzrokowej), jakim dysponuje człowiek. W tym wypadku odbiór sztuki przebiega w sposób bezpośredni - osoba niewidząca, choć postrzega zaledwie wybrane aspekty dzieła, robi to samodzielnie. Bezpośredni kontakt ze sztuką wizualną jest dla niej natomiast zupełnie niemożliwy. W szczególnie trudnej sytuacji znajdują się osoby, które straciły wzrok w trakcie życia:

W przypadku tej grupy osób nie można mówić o ich funkcjonowaniu jedynie w obszarze rzeczywistości pozawizualnej, mimo że aktualnie tylko ona jest im dostępna. Pamięć świata pełnego światła, barw i cieni na tyle jest istotna, że powoduje nieustanne, mimo iż już tylko wyobrażeniowe - bycie w jej obszarze. Fakt ten istotny jest dla rozważań preferencji estetycznych osób ociemniałych. Z całą pewnością wyznaczy on specyfikę ukształtowania tej sfery. Być może wyrazi się związaniem przeżycia piękna ze wszystkim, co minione, a co dostępne jest jedynie percepcji wzrokowej. Być może zdeterminuje niemożność dostrzeżenia piękna w tym wszystkim, co dane bezwzrokowo ${ }^{36}$.

Zachowana pamięć wzrokowa daje osobom ociemniałym szansę na pełniejsze wyobrażenie sobie wizualnych aspektów dzieła sztuki. Jednocześnie brak bezpośredniego dostępu do dzieła może wywoływać poczucie „straty” wobec posiadanej niegdyś percepcji wzrokowej. Zdarza się, że konieczność bezwzrokowego odbioru sztuki utrudnia lub uniemożliwia osobie ociemniałej jej percepcję, w skrajnych przypadkach znacznie obniżając jakość przeżycia estetycznego. Osoby ociemniałe i niewidome, choć posiadają różne doświadczenia w obszarze poznania otaczającej rzeczywistości, w sytuacji obcowania z dziełem sztuki znajdują się w takiej samej sytuacji - nie mają dostępu do jego warstwy wizualnej. Błędne byłoby jednak przekonanie, że dzieła sztuki wizualnej pozostają niedostępne dla osób z niepełnosprawnością wzroku. Kluczem, który otwiera im drzwi do świata kultury i sztuki, jest audiodeskrypcja.

${ }^{36}$ U. Zuberek, Pozawizualne doznania estetyczne. Wstęp do badań nad wrażliwościa na piękno osób z głębokim defektem wzroku, [w:] Wymiary piękna. Z badań estetyki sensu largo, pod red. M. Gołaszewskiej, Kraków 1998, s. 28. 


\section{Audiodeskrypcja - powstanie i rozpowszechnienie}

Audiodeskrypcja jest techniką opisu treści wizualnych przeznaczoną dla osób z niepełnosprawnością wzroku. Wywodzi się ze Stanów Zjednoczonych. Jej teoretyczne podstawy już w latach 70. XX w. opracował Gregory Frazier z San Francisco State University ${ }^{37}$. Po raz pierwszy audiodeskrypcja została wykorzystana podczas spektaklu w teatrze Arena Stage w Waszyngtonie w $1981 \mathrm{r}$. Inicjatorami wydarzenia byli niewidoma Margaret Pfanstiehl i jej mąż. Metoda szybko zyskała popularność i już pod koniec tej samej dekady spektakle opatrzone opisem dla osób niewidzących odbywały się w 50 amerykańskich placówkach kulturalnych. W tym samym czasie metodę zaczęto stosować w krajach europejskich ${ }^{38}$.

Początki audiodeskrypcji w Polsce sięgają lat 90. XX w. Wówczas, dzięki pionierskiej inicjatywie Andrzeja Wocha, zaczęto tworzyć polskie tyflofilmy. Idea zakładała udostępnienie rodzimych produkcji osobom z niepełnosprawnością wzroku. Do filmów nagranych na kasety VHS dodawano ścieżkę dźwiękową. Ścieżka ta zawierała opis warstwy wizualnej filmu ${ }^{39}$.

Bardzo ważny dla rozwoju polskiej audiodeskrypcji był rok 2006. W tym czasie swą działalność rozpoczęła, nieformalna jeszcze wówczas, grupa „Audiodeskrypcja”, zawiązana w Białymstoku z inicjatywy Barbary Szymańskiej i Tomasza Strzymińskiego ${ }^{40}$. Założyciele grupy, bazując na standardach obowiązujących w innych krajach i przenosząc je na rodzimy grunt, opracowali polskie zasady tworzenia opisów. Pierwszym w kraju wydarzeniem z audiodeskrypcją był pokaz filmu „Statyści”, który odbył się

37 B. Szymańska, T. Strzymiński, Standardy tworzenia audiodeskrypcji do produkcji audiowizualnych [online]. Białystok: Fundacja Audiodeskrypcja, 2010, 42 s. [dostęp 31 maja 2016]. Dostępny w World Wide Web: http://avt.ils.uw.edu.pl/files/2010/12/ AD-_standardy_tworzenia.pdf.

38 Tamże.

${ }^{39}$ M. Czerwińska, Halski polskiego tyflofilmu, [w:] Książka bez Barier. Materiały z Ogólnopolskiej Konferencji Poznań-Stęszew, 18-20 IX 2000 r., pod red. J. Nowickiego, Warszawa 2000, s. 68-69.

${ }^{40}$ Grupa przekształciła się w Fundację „Audiodeskrypcja”. Jest to organizacja pozarządowa działająca na rzecz udostępniania kultury osobom z niepełnosprawnością wzroku. Zob. Fundacja „Audiodeskrypcja” [online] [dostęp 31 maja 2016]. Dostępny w World Wide Web: http://www.audiodeskrypcja.org.pl/. 
w białostockim kinie „Pokój” 27 listopada 2006 r. ${ }^{41}$ Pozytywny odbiór przedsięwzięcia pomógł w szybkim rozpowszechnieniu tej metody. W kolejnych latach stopniowo wzrastała liczba podobnych inicjatyw, przyczyniając się zarazem do poszerzania obszaru zastosowania audiodeskrypcji. Już w 2007 r. na stronie internetowej Telewizji Polskiej udostępniono pierwszy serial z audiodeskrypcją („Ranczo”). W tym samym roku film z audiodeskrypcją zaprezentowano na XXXII Festiwalu Filmów Fabularnych w Gdyni. Warto podkreślić, że był to pierwszy na świecie festiwal filmowy, podczas którego wyemitowano film z audiodeskrypcją ${ }^{42}$. Z inicjatywy Fundacji „Audiodeskrypcja” organizowano pierwsze szkolenia mające na celu przygotowanie specjalistów tworzących opisy.

Obecnie audiodeskrypcja (wraz z językiem migowym oraz napisami dla osób niesłyszących) znajduje się w wykazie udogodnień, jakie dostawcy usług audiowizualnych zobowiązani są udostępniać swoim odbiorcom $^{43}$. Pierwszym polskim aktem prawnym, który reguluje tę kwestię, jest Ustawa o radiofonii i telewizji z 2011 r. Definicja audiodeskrypcji zawarta w dokumencie brzmi następująco:

audiodeskrypcją jest werbalny, dźwiękowy opis obrazu i treści wizualnych zawartych w audycji audiowizualnej przeznaczony dla osób niepełnosprawnych z powodu dysfunkcji narządu wzroku, umieszczony $\mathrm{w}$ audycji lub rozpowszechniany równocześnie z audycją ${ }^{44}$.

Obowiązek udostępniania programów z audiodeskrypcją jest rezultatem przystosowania polskiego prawa do prawodawstwa Unii Europejskiej. Wymóg nadawania programów audiowizualnych $\mathrm{w}$ formie dostępnej dla osób z niepełnosprawnością sensoryczną ujęty jest w Dyrektywie Parlamentu Europejskiego i Rady z dnia 11 grudnia 2007 r. dotyczącej świadczenia usług medialnych:

${ }^{41}$ B. Szymańska, T. Strzymiński, dz. cyt., s. 8.

42 Tamże.

43 B. Szymańska, Audiodeskrypcja - milowy krok w stronę dostępności kultury dla osób z niepełnosprawnościq wzroku, „Wiadomości o Równości” 2012, nr 1, s. 24-26 [dostępny także online: http://www.don.uj.edu.pl/documents/1686948/d8393a58-1926-4a61941e-7ffda1967112].

44 Ustawa z dnia 25 marca 2011 r. o zmianie ustawy o radiofonii i telewizji oraz niektórych innych ustaw, Dz.U. 2011, nr 85, poz. 459, art. 4, pkt 28. 
Prawo osób niepełnosprawnych i osób starszych do integracji i uczestnictwa w życiu społecznym i kulturalnym Wspólnoty jest nierozłącznie związane ze świadczeniem dostępnych audiowizualnych usług medialnych. Środki pozwalające na osiągnięcie dostępności powinny obejmować między innymi: język migowy, wyświetlane listy dialogowe, dźwiękowa ścieżka narracyjna oraz prosta w obsłudze nawigacja ${ }^{45}$.

Obecnie wydarzenia z audiodeskrypcją odbywają się w miastach na terenie niemal całego kraju ${ }^{46}$. Chociaż kinowe projekcje filmów $\mathrm{z}$ audiodeskrypcją wciąż mają jedynie charakter okazjonalny, to warto zauważyć, iż w ostatnich latach stopniowo wzrasta liczba filmów opatrzonych dodatkowym opisem. Część z nich możliwa jest do zakupienia na płytach DVD - do 2010 w Polsce ukazało się 28 tytułów z audiodeskrypcją (m.in. Afonia i pszczoły, Katyń, Madagaskar 2, Parę osób, mały czas ${ }^{47}$. Alternatywą wobec filmów na płytach jest portal internetowy Adapter, stworzony przez Fundację na Rzecz Rozwoju Audiodeskrypcji „Katarynka”. W portalu bezpłatnie udostępniane są filmy z audiodeskrypcją dla osób niewidzących oraz z napisami dla osób niesłyszących ${ }^{48}$. Audiodeskrypcję coraz częściej wykorzystuje się także w muzeach i galeriach sztuki. Aktywną działalność na rzecz ich przystosowania do potrzeb osób z niepełnosprawnością wzroku prowadzi Fundacja Kultury Bez Barier. Wśród udostępnionych przez nią miejsc i obiektów wymienić można wybrane ekspozycje prezentowane m.in. w Muzeum Narodowym w Warszawie, Zamku Królewskim, Fabryce Schindlera czy w Muzeum Pomorza Środkowego w Słupsku ${ }^{49}$.

45 Dyrektywa 2007/65/WE Parlamentu Europejskiego i Rady z dnia 11 grudnia 2007 r. zmieniająca dyrektywę Rady 89/552/EWG w sprawie koordynacji niektórych przepisów ustawowych, wykonawczych i administracyjnych państw członkowskich, dotyczacych wykonywania telewizyjnej działalności transmisyjnej, Dz.Urz. UE, L 332, pkt (64).

46 Zob. np. Centrum Kultury Wrocław-Zachód [online] [dostęp 31 maja 2016]. Dostępny w World Wide Web: http://ckwz.art.pl/audiodeskrypcja.html; Pomorska Fundacja Filmowa w Gdyni [online] [dostęp 31 maja 2016]. Dostępny w World Wide Web: http:// www.pisf.pl/aktualnosci/warsztaty-audiodeskrypcji.

${ }^{47}$ Lista filmów audiodeskrybowanych, [w:] Białą laska po kinowym ekranie. Wprowadzenie do sztuki filmowej i audiodeskrypcji dla osób słabowidzących i niewidomych, pod red. W. Ziółkowskiego, Warszawa 2010, s. 36.

${ }^{48}$ Adapter [online] [dostęp 31 marca 2016]. Dostępny w World Wide Web: http:// adapter.pl/.

49 Muzeum Poza Cisza i Ciemnościa [online] [dostęp 31 maja 2016]. Dostępny w World Wide Web: http://kulturabezbarier.org/projekty,m,mg,40,187,168,160. 


\section{Audiodeskrypcja kluczem do kultury i sztuki}

Termin audiodeskrypcja składa się z dwóch członów: audio (łac. - wskazujący na związek ze słuchem) oraz deskrypcja (łac. descriptio - rysowanie, opisywanie). Z ich zestawienia powstaje termin oznaczający opis nadawany drogą słuchową ${ }^{50}$. Audiodeskrypcja jest werbalnym przekazem treści wizualnych wyrażonym w formie dźwiękowej, odczytywanym na żywo lub nagranym na trwałym nośniku. Opis taki dostarcza osobie z niepełnosprawnością wzroku informacji, których nie może ona percypować w sposób bezpośredni.

Odbiorcy audiodeskrypcji to grupa silnie zróżnicowana. Przyjmując za kryterium podziału stopień uszkodzenia wzroku, wyróżnia się wśród nich osoby niewidzące (zarówno niewidome, jak też ociemniałe) oraz osoby niedowidzące. Druga klasyfikacja zakłada podział na niewidomych i ociemniałych, a więc dokonywana jest ze względu na czas wystąpienia niepełnosprawności ${ }^{51}$. Z punktu widzenia audiodeskryptora tworzącego opis szczególnie istotny jest drugi podział. Członkowie wskazanych grup mają skrajne doświadczenia w obrębie znajomości kolorów, wyobraźni przestrzennej czy perspektywy. Osoby, które straciły wzrok w trakcie życia i zachowały pamięć wzrokową, nie potrzebują tak szczegółowych informacji jak te, które nigdy nie widziały. Najlepszym rozwiązaniem byłoby wykonywanie kilku wersji opisów. Póki co tworzy się jednak jedną wersję audiodeskrypcji ${ }^{52}$. Powodami są m.in.: czasochłonność takiego przedsięwzięcia, zwielokrotnienie nakładów finansowych (zależne od liczby wersji audiodeskrypcji) oraz wciąż niewystarczające grono specjalistów z tego zakresu. Pełna definicja audiodeskrypcji brzmi następująco:

Audiodeskrypcja to werbalny, dźwiękowy opis obrazu i treści wizualnych zawartych w audycji audiowizualnej, przeznaczony dla osób

50 B. Szymańska, dz. cyt., s. 24.

51 I. Künstler, U. Butkiewicz, Audiodeskrypcja - zasady tworzenia [online]. Warszawa: Fundacja Kultury bez Barier, 2012, 10 s. [dostęp 31 maja 2016]. Dostępny w World Wide Web: http://dzieciom.pl/wp-content/uploads/2012/09/Audiodeskrypcja-zasady-tworzenia.pdf.

52 Tamże. 
niepełnosprawnych z powodu dysfunkcji wzroku, umieszczony w audycji lub rozpowszechniany równocześnie $\mathrm{z}$ audycją ${ }^{53}$.

Audiodeskrypcja wykorzystywana jest też podczas spektakli teatralnych i wydarzeń widowiskowych, za jej pomocą opisuje się eksponaty muzealne, wystawy oraz obiekty architektoniczne.

Przygotowanie opisu do poszczególnych rodzajów dzieł i wydarzeń jest pracą wieloetapową ${ }^{54}$. Pierwsza czynność audiodeskryptora polega na dokładnym zapoznaniu się z obiektem, do którego zamierza on stworzyć opis. Film lub inny materiał audiowizualny należy obejrzeć w całości. Pozwala to ustalić kwestie, takie jak: wyodrębnienie scen szczególnie istotnych dla przebiegu akcji; określenie czasu, jaki mogą zająć opisy poszczególnych scen ${ }^{55}$; ustalenie, w których momentach zostaną zaprezentowane poszczególne postacie uczestniczące w akcji; poznanie ogólnego klimatu filmu, jego specyfiki i środków wyrazu, jakimi się w nim posłużono. Jeśli audiodeskrypcja ma dotyczyć dzieła sztuki, to konieczne jest zapoznanie się z techniką artystyczną, w której zostało ono wykonane (np. kierunek w malarstwie, styl w architekturze itp.). Informacje należy uzupełnić o historię dzieła, znane interpretacje, dane o autorze/ /twórcy.

Drugi etap w dużym stopniu łączy się z pierwszym. Audiodeskryptor dokonuje selekcji zgromadzonego materiału i wybiera te informacje, które zamierza włączyć do opisu. Pozostałe, nawet jeśli nie zostaną zamieszczone w tekście, pozwalają mu przygotować się do wykonania opisu w możliwie profesjonalny sposób. Audiodeskryptor może (i powinien) wspomagać się też słownikami specjalistycznymi i tekstami fachowymi. W trakcie pracy przydatne okazują się również słowniki i poradniki ję-

53 Ustawa z dnia 25 marca 2011 r.o zmianie ustawy o radiofonii i telewizji oraz niektórych innych ustaw, Dz.U. 2011, nr 85, poz. 459, art. 3, pkt 28.

${ }^{54}$ Etapy przygotowania tekstu audiodeskrypcji opracowane na podstawie I. Künstler, U. Butkiewicz, dz. cyt., s. 1-2; B. Szymańska, T. Strzymiński, dz. cyt., s. 13-21, 40-41.

${ }_{55}$ Audiodeskrypcja do filmu ma formę dodatkowej ścieżki dźwiękowej zawierającej opis scen i występujących w nich postaci. Ścieżka audiodeskrypcji emitowana jest równocześnie z główną ścieżką dźwiękową filmu, ale nie może nakładać się na nią - opisy muszą „mieścić się” w przerwach pomiędzy dialogami. Z tego powodu bardzo ważny jest podział scen na te, które zostaną opisane szczegółowo (najważniejsze dla akcji filmu) oraz te, których opisy mogą być krótsze i mniej szczegółowe (np. z powodu braku odpowiedniej ilości czasu). 
zykowe - język audiodeskrypcji powinien być ciekawy, barwny, bogaty w epitety, obrazowe określenia i porównania.

Następnie tekst audiodeskrypcji redagowany jest według ustalonego planu. Plan obejmuje m.in. wybór opisywanych scen, hierarchizację informacji (jeśli trzeba ograniczyć się do podania informacji najistotniejszych), ustalenie kolejności, w jakiej elementy dzieła zostaną opisane. Gotowy tekst audiodeskrypcji to skrypt. Skrypt jest dwukrotnie konsultowany: najpierw z innym audiodeskryptorem, a następnie z osobą niewidzącą.

Ostatni etap pracy polega na nagraniu skryptu. Jest on równie ważny jak przygotowanie tekstu: „od treści opisu i od sposobu odczytania zależy jakość audiodeskrypcji, a co za tym idzie, przyjemność i radość, jaką mogą z niej czerpać odbiorcy"56.

Osoba czytająca skrypt musi mieć odpowiednie predyspozycje: „Właściwa koordynacja czynności krtani, rezonatorów głosowych, układu oddechowego sprawia, że klimat opisywanego obrazu zostaje zachowany, a treść wizualna obrazu zachowuje swój właściwy charakter" ${ }^{57}$. Najlepiej jeśli osobą odczytującą skrypt jest sam jego autor - zna tekst i jest świetnie zaznajomiony z dziełem/zorientowany w akcji filmu. Jeżeli skrypt odczytuje inna osoba (może to być zawodowy lektor zatrudniony do tego zadania), to audiodeskryptor umieszcza w tekście dokładne wskazówki dotyczące tempa i sposobu czytania poszczególnych fragmentów ${ }^{58}$.

\section{Podsumowanie}

Czynnikiem, który w największym stopniu wpływa na jakość audiodeskrypcji, jest osoba audiodeskryptora. W jego pracy ważne są dwie kwestie. Pierwsza to kompetencje z zakresu wykonywania opisów.

56 B. Szymańska, dz. cyt., s. 24.

57 Tamże.

58 Audiodeskryptor umieszcza w tekście wskazówki nawet wtedy, gdy osobiście nagrywa tekst. Jeżeli jednak powierza to zadanie innej osobie, to od precyzji i rzetelności jego wskazówek uzależniona jest jakość uzyskanego nagrania. Uwagi dotyczące tempa czytania są istotne w skryptach audiodeskrypcji do produkcji audiowizualnych, gdzie rytm opisu uzależniony jest od szybkości następujących po sobie scen. Ścieżka audiodeskrypcji musi być zsynchronizowana z główną ścieżką dźwiękową filmu czy programu 
Druga - znajomość środowiska odbiorców. Wiedza na temat niepełnosprawności wzrokowej, znajomość jej rodzajów i - implikowanych przez nie - specyficznych trudności w odbiorze bodźców zmysłowych pozwala rozumieć potrzeby osób niewidzących. Podczas każdego etapu swojej pracy audiodeskryptor wychodzi naprzeciw tym potrzebom. Poznając dzieło/obiekt, który ma opisać, za pomocą własnego zmysłu obserwacji stara się dostrzec wszystkie jego cechy i szczegóły, które następnie przekaże odbiorcom. Selekcjonując zebrany materiał, wybiera najważniejsze i najciekawsze informacje. Uzupełniając audiodeskrypcję o dodatkowe wiadomości, systematyzuje wiedzę osób niewidzących na temat nurtów w sztuce czy środków artystycznego wyrazu. W dbałości o potrzeby odbiorcy audiodeskryptor konsultuje skrypt. Odczytanie tekstu „na próbę” pozwala mu wyeliminować wyrażenia nieścisłe, zbyt ogólne, niezrozumiałe dla osób niewidzących, które dla autora tekstu osoby widzącej - mogą być niezauważalne.

Audiodeskrypcja to technika szybko się rozwijająca. Chociaż znana jest w Polsce od niecałej dekady, to już znalazła zastosowanie w udostępnianiu różnorodnych form działalności kulturalnej i artystycznej docelowej grupie odbiorców. Audiodeskrypcja znajduje się też w kręgu zainteresowania badań naukowych. W naukach przekładoznawczych ujmowana jest jako odmiana tłumaczenia medialnego ${ }^{59}$. W ujęciu nauk pedagogicznych analizuje się jej rolę w edukacji dzieci z niepełnosprawnością wzroku ${ }^{60}$.

Zasięg rozpowszechnienia audiodeskrypcji na razie nie pokrywa się z liczbą wydarzeń, podczas których jest ona stosowana. Biorąc pod uwagę dotychczasowe tempo rozwoju tej techniki, można jednak oczekiwać, że i ta kwestia szybko ulegnie poprawie.

audiowizualnego. Opis w technice audiodeskrypcji wykonywany do dzieł „statycznych” (obraz, budynek, rzeźba) na ogół nie ma ścisłych ograniczeń czasowych.

59 A. Szarkowska, Przekład audiowizualny w Polsce - perspektywy i wyzwania, „Przekładaniec” 2009, nr 20, s. 8-25; M. Tryuk, Co to jest tłumaczenie audiowizualne?, „Przekładaniec" 2009, nr 20, s. 26-39.

${ }^{60}$ A. Walczak, M. Rubaj, Audiodeskrypcja na lekcji historii, biologii i fizyki $w$ klasie uczniów z dysfunkcja wzroku, „Przekładaniec” 2014, nr 28, s. 63-79; W. Figiel, Percepcja audiodeskrypcji wśród nauczycieli szkół specjalnych, „Przekładaniec’ 2014, nr 20, s. 93-108. 


\section{Bibliografia}

Adapter [online] [dostęp 31 maja 2016]. Dostępny w World Wide Web: http:// adapter.pl/.

Benedikt Antoni, Mowa ciała, Wrocław 2002.

Biała laskq po kinowym ekranie. Wprowadzenie do sztuki filmowej i audiodeskrypcji dla osób słabowidzq̨cych i niewidomych, pod red. Wojciecha Ziółkowskiego, Warszawa 2010.

Centrum Kultury Wrocław-Zachód [online] [dostęp 31 maja 2016]. Dostępny w World Wide Web: http://ckwz.art.pl/audiodeskrypcja.html.

Czerwińska Małgorzata, Halski polskiego tyflofilmu, [w:] Książka bez Barier. Materiały z Ogólnopolskiej Konferencji Poznań-Stęszew, 18-20 IX 2000 r., pod red. Janusza Nowickiego, Warszawa 2000, s. 68-71.

Czerwińska Małgorzata, Osoby z niepełnosprawnościq wzroku, [w:] Ochonczenko Helena, Czerwińska Małgorzata, Garbat Marcin, Osoby z niepełnosprawnościq w szkole wyższej. Wybrane zagadnienia, Zielona Góra 2011, s. 11-28. Dykcik Władysław, Wprowadzenie w przedmiot pedagogiki specjalnej jako nauki, [w:] Pedagogika specjalna, pod red. Władysława Dykcika, Poznań 2002, s. 13-64.

Dyrektywa 2007/65/WE Parlamentu Europejskiego i Rady z dnia 11 grudnia 2007 r. zmieniająca dyrektywę Rady 89/552/EWG w sprawie koordynacji niektórych przepisów ustawowych, wykonawczych i administracyjnych państw członkowskich, dotyczacych wykonywania telewizyjnej działalności transmisyjnej, Dz.Urz. UE, L 332.

Działalność ONZ [online] [dostęp 31 maja 2016]. Dostępny w World Wide Web: http://www.unic.un.org.pl/niepelnosprawnosc/dzialalnosc.php?druk=1. Eco Umberto, Sztuka, przeł. Piotr Salwa, Mateusz Salwa, Kraków 2008.

Fedorowicz Małgorzata, Człowiek niepełnosprawny w bibliotece publicznej, Toruń 2010.

Fedorowicz Małgorzata, Specjalne materiały czytelnicze dla osób niepełnosprawnych, Toruń 2002.

Figiel Wojciech, Percepcja audiodeskrypcji wśród nauczycieli szkół specjalnych, „Przekładaniec” 2014, nr 20, s. 93-108.

Fundacja „Audiodeskrypcja” [online] [dostęp 31 maja 2016]. Dostępny w World Wide Web: http://www.audiodeskrypcja.org.pl/.

Gołaszewska Maria, Zarys estetyki, Warszawa 1984.

Ingarden Roman, Wybór pism estetycznych, oprac. Andrzej Tyszczyk, Kraków 2005. 
Kalbarczyk Marek, Obok jest osoba niewidoma, Warszawa 2014.

Kirenko Janusz, Gindrich Piotr, Odkrywanie niepełnosprawności wzrokowej w nauczaniu włączającym, Lublin 2007.

Konwencja o prawach osób niepełnosprawnych, Dz.U. 2012, poz. 1169.

Künstler Izabela, Butkiewicz Urszula, Audiodeskrypcja - zasady tworzenia [online]. Warszawa: Fundacja Kultury bez Barier, 2012, 10 s. [dostęp 31 maja 2016]. Dostępny w World Wide Web http://dzieciom.pl/wp-content/ uploads/2012/09/Audiodeskrypcja-zasady-tworzenia.pdf.

Mellor Michael, Louis Braille, dotyk geniuszu, przeł. Eryk Zieliński, Marek Kalbarczyk, Warszawa 2009.

Mosty zamiast murów. Podręcznik komunikacji interpersonalnej, pod red. Johna Stewarta, Warszawa 2000.

Muzeum Poza Ciszq i Ciemnością [online] [dostęp 31 maja 2016]. Dostępny w World Wide Web: http://kulturabezbarier.org/projekty,m,mg,40,187,168,160. Ossowski Stanisław, U podstaw estetyki, Warszawa 1958.

Pomorska Fundacja Filmowa w Gdyni [online] [dostęp 31 maja 2016]. Dostępny w World Wide Web: http://www.pisf.pl/aktualnosci/warsztaty-audiodeskrypcji.

Program „Aktywny Samorząd” [online] [dostęp 31 maja 2016]. Dostępny w World Wide Web: http://www.pfron.org.pl/pl/programy-i-zadania-pfr/aktywnysamorzad/1644,Pilotazowy-program-Aktywny-samorzad.html.

Sękowska Zofia, Pedagogika specjalna: zarys, Warszawa 1985.

Szarkowska Agnieszka, Przekład audiowizualny w Polsce - perspektywy i wyzwania, „Przekładaniec” 2009, nr 20, s. 8-25.

Szymańska Barbara, Audiodeskrypcja - milowy krok w stronę dostępności kultury dla osób z niepełnosprawnościq wzroku, „Wiadomości o Równości” 2012, nr 1, s. 24-26 [dostępny także online: http://www.don.uj.edu.pl/ documents/1686948/d8393a58-1926-4a61-941e-7ffda1967112].

Szymańska Barbara, Strzymiński Tomasz, Standardy tworzenia audiodeskrypcji do produkcji audiowizualnych [online]. Białystok: Fundacja Audiodeskrypcja, 2010, 42 s. [dostęp 31 maja 2016]. Dostępny w World Wide Web: http:// avt.ils.uw.edu.pl/files/2010/12/AD__standardy_tworzenia.pdf.

Tryuk Małgorzata, Co to jest tłumaczenie audiowizualne?, „Przekładaniec” 2009, nr 20, s. 26-39.

Uchwała Sejmu Rzeczypospolitej Polskiej z dnia 1 sierpnia 1997 r. - Karta Praw Osób Niepełnosprawnych, M. P. 1997, nr 50, poz. 475. 
Ustawa o rehabilitacji zawodowej i społecznej oraz zatrudnianiu osób niepełnosprawnych, Dz.U. 1997, nr 123, poz. 776.

Ustawa z dnia 19 sierpnia 2011 r. o języku migowym i innych środkach komunikowania się, Dz.U. 2011, nr 209, poz. 1243.

Ustawa z dnia 25 marca 2011 r. o zmianie ustawy o radiofonii i telewizji oraz niektórych innych ustaw, Dz.U. 2011, nr 85, poz. 459.

Walczak Agnieszka, Rubaj Maria, Audiodeskrypcja na lekcji historii, biologii i fizyki w klasie uczniów z dysfunkcjq̨ wzroku, „Przekładaniec” 2014, nr 28, s. 63-79.

Zaorska Marzenna, Głuchoniewidomi w Polsce. Specjalna pomoc, edukacja i rehabilitacja, Olsztyn 2002.

Zuberek Urszula, Pozawizualne doznania estetyczne. Wstęp do badań nad wrażliwością na piękno osób z głębokim defektem wzroku, [w:] Wymiary piękna. $Z$ badań estetyki sensu largo, pod. red. Marii Gołaszewskiej, Kraków 1998, s. 13-43.

\section{Audiodescription: A Key to the World of Art and Culture for the Visually Impaired}

ABSTRACT: The turn of the $20^{\text {th }}$ and $21^{\text {st }}$ centuries is a period marked by an increasing interest in the issue disability. The number of initiatives aimed to socially integrate the disabled and improve their living conditions has been rising steadily ever since. It should be, however, noted that their participation in various forms of cultural activity is limited. This problem is especially acute for those with sensory impairments.

The aim of the present article is to analyse the problem of participation in culture from the perspective of the visually impaired. First, the author addresses the limits in the spheres of perception and communication due to the impairment itself. This description will help to indicate which domains of artistic activity and aspects of a work of art are inaccessible to the visually impaired. The subsequent parts of the article describe audiodescription, a technique that allows for a greater participation of the visually impaired in culture and art.

KEYWORDS: access to art and culture, audiodescription, social aspects of visual impairment. 